\title{
EFFECT OF LEVELS AND SOURCES OF PROTEIN ON THE PERFORMANCE AND NUTRIENT DIGESTIBILITY IN BLACK BENGAL GOAT
}

\author{
M. B. Ullah ${ }^{1}$, K. M. S. Islam ${ }^{1}$, M. A. Akbar ${ }^{1}$, A. B. M. Khaleduzzaman ${ }^{2}$ and \\ M. R. Debi ${ }^{1}$
}

\begin{abstract}
Sixteen castrated male Black Bengal goats (aged between 8 and 10 months and average live weight $9.16 \mathrm{~kg}$ ) were used in a $2 \times 2$ factorial design to study the effect of protein levels and sources on growth and nutrient digestibility under intensive condition for 56 days. The sources of protein were mustard oil cake (MOC) and soybean meal (SBM). Level of protein in each sources were 22 (HP-high protein) and 16 (LP-low protein) percentage. The dietary treatments were $\left(\mathrm{T}_{1}\right) \mathrm{MOC}$-HP, $\left(T_{2}\right)$ MOC-LP, $\left(T_{3}\right)$ SBM-HP and $\left(T_{4}\right)$ SBM-LP. Concentrate diets as well as dal grass was fed throughout the experimental period and last week considered for digestibility trial. Average daily live weight gain of goats was 42, 41, 43, and $52 \mathrm{~g}$ for the diets $T_{1}, T_{2}, T_{3}$ and $T_{4}$ respectively. The result showed no significant $(P>0.05)$ variation between protein sources and their levels on growth performance. Intake of DM was 425, 389, 407 and $437 \mathrm{~g} / \mathrm{d}$ which were 4.2, 3.8, 4.0 and 4.1 percent of their body weight for the diets $T_{1}, T_{2}, T_{3}$ and $T_{4}$ respectively. Intake of CP was 59,46 , 56 and $50 \mathrm{~g} / \mathrm{d}$ respectively. The sources of protein did not influence the intake of $\mathrm{CP}$ $(P>0.05)$, but their levels had $(P<0.05)$ effect on it. Digestibility of DM was 62,58 , 69 and 68 percent respectively. OM digestibility $(\mathrm{g} / 100 \mathrm{~g})$ was $67,64,71$ and 73 for the diets $T_{1}, T_{2}, T_{3}$ and $T_{4}$ respectively. Digestibility $(\mathrm{g} / 100 \mathrm{~g})$ of CP was $62,60,70$ and 69 for the diets $T_{1}, T_{2}, T_{3}$ and $T_{4}$ respectively. Thus the result showed that the digestibility of DM, CP and OM was significantly higher for SBM than MOC but their levels varied insignificantly. Therefore low protein supplementation (16\%) in a concentrate mixture containing mustard oil cake and/or soybean meal could be suggested for optimizing growth performance of Black Bengal Goat under intensive management system.
\end{abstract}

Key words: Goats, Mustard oil cake, Soybean meal, Growth, Intake, Digestibility

\section{Introduction}

Bangladesh has 15.20 million goats (BBS, 2008). Small, marginal and landless farmers contributed $75.8 \%$ and medium and large farmers contributed $24.2 \%$ of goat farming in rural areas (Huque, 2008). Most of the farmers manage their goats in free range system without any supplementation. Some findings reflected that only grazing might not be sufficient for weight gain of goats (Kochcpakdee et al., 1994). Farmers are now trying to

\footnotetext{
${ }^{1}$ Department of Animal Nutrition, Bangladesh Agricultural University, Mymensingh-2202, Bangladesh

2 Department of Livestock Services, Krishikhamar Sarak, Farmgate, Dhaka-1215, Bangladesh
}

(Received: October 10, 2009) 
adapt and rear goat under intensive management system. Energy and protein concentrations of the diet play a significant role on growth of goats (Hadjipanayiotou et al., 1996). On the other hand performance of goats was mostly similar feeding different sources of protein and their levels (Sahlu et al., 2004). However, reports on the contribution of dietary protein sources and their level to the performance of Black Bengal Goat under Bangladesh condition are scanty. Under the above situation it is essential to study the requirement of protein for goats from different sources. Among protein sources soybean meal (SBM) and mustard oil cake (MOC) are commonly available for livestock. Therefore present experiment was undertaken to investigate the effects of levels (Low and High) and sources (SBM and MOC) of dietary protein on growth performance and nutrient digestibility of Black Bengal goats under intensive management in Bangladesh.

\section{Materials and Methods}

The study was conducted at the Sahjalal Animal Nutrition Field Laboratory, Bangladesh Agricultural University, Mymensingh for a period of 56 days. Sixteen castrated male Black Bengal goats (approximately 8 to 10 months of age weighing on an average 9.16 $\mathrm{kg}$ ) were purchased from local market. The animals were adapt for 20 days with the experimental conditions and were introduced to the experimental feeds prior to the commencement of the study. The treatment arrangement was $2 \times 2$ factorial which was made by blocking sixteen animals into four groups based on live weight. Each treatment consisted of either low or high level of protein each at either mustard oil cake or soybean meal sources (Table 1). Diets differing in protein sources were mustard oil cake (MOC) and soybean meal (SBM) as well as two levels (g/100g DM) for each source was 22 (HP-high protein) and 16 (LP-low protein) which is $15 \%$ above and below as recommended by BLRI (2002) and diets were iso-energetic.

The animals were weighted at 7.00 am prior to morning feeding. The initial live weight of each goat was taken at the beginning of the experiment for three consecutive days and the mean weights were recorded as initial weight. Thereafter, animals were weighted individually in every 7-days interval throughout the experimental period. Final live weight of each animal was taken as an average weight of two consecutive days after completion of 56 days trial.

Total mixed ration were supplied according to the requirement of body weight. The roughage (Dal grass) and concentrate of the diets were fed separately. Fresh drinking water was made available at all times. A conventional digestibility trial was conducted at the end of the trial for 7 days to assess the utilization of dietary nutrient by the goats. During digestibility trial a portion of feces samples was preserved in a refrigerator at $20^{\circ} \mathrm{C}$ for DM and nitrogen estimation. Another portion of feces sample and feed refusal collected during digestibility trial was sun dried and preserved in airtight polythene bags 
for determination of other proximate components following the methods as described by AOAC (1980). Energy were estimated from the ME values of feed ingredients (Banerjee, 1998 and Ranjhan, 1980). The data were analyzed using the "SPSS" statistical programme.

Table 1. Ingredients composition of concentrate mixture

\begin{tabular}{|l|c|c|c|c|}
\hline \multirow{2}{*}{ Parameters } & \multicolumn{4}{c|}{ Dietary treatments ${ }^{\#}$} \\
\cline { 2 - 5 } & $\mathbf{T}_{\mathbf{1}}$ & $\mathbf{T}_{\mathbf{2}}$ & $\mathbf{T}_{\mathbf{3}}$ & $\mathbf{T}_{\mathbf{4}}$ \\
\hline Ingredients/Composition (g/100g) & & & & \\
Wheat bran & 35 & 20 & 20 & 16 \\
Rice polish & 8 & 18 & 12 & 18 \\
Maize & 10 & 38 & 26 & 46 \\
Mustard oil cake & 45 & 22 & - & - \\
Soybean meal & - & - & 40 & 18 \\
Premix & 1 & 1 & 1 & 1 \\
Salt & 1 & 1 & 1 & 1 \\
Nutrient composition & & & & \\
DM (g/100g) & 87.3 & 86.8 & 87.1 & 86.6 \\
CP (g/100g DM) & 21.9 & 15.6 & 21.8 & 15.5 \\
ME (MJ/kg DM) & 10.5 & 10.6 & 10.5 & 10.6 \\
\hline
\end{tabular}

${ }^{\#} \mathrm{~T}_{1}=$ Mustard oil cake-high protein (22\%), $\mathrm{T}_{2}=$ Mustard oil cake-low protein (16\%), $\mathrm{T}_{3}=$ Soybean meal-high protein (22\%), $\mathrm{T}_{4}=$ Soybean meal-low protein (16\%)

\section{Results and Discussion}

\section{Growth performance}

The live weight gain (g/d) of goats was $42,41,43$ and 52 for the diets $T_{1}, T_{2}, T_{3}$ and $T_{4}$ respectively (Table 2 ). The result showed that there was no significant $(P>0.05)$ variation between protein sources and their levels on the performance of goats. Previous studies (Shahjalal et al., 1992) indicated that sources of nitrogen supplementation had no effect on weight gain of Angora goats. The growth performance of SBM supplemented diets $(47 \mathrm{~g} / \mathrm{d})$ was higher than MOC supplemented diet $(42 \mathrm{~g} / \mathrm{d})$. Rahman (2001) found the same result and showed that growth rate of Black Bengal goats on SBM supplemented diet was numerically higher than til oil cake supplemented diet. The higher growth rate in SBM supplemented diet may be due to the presence of higher amount of UDP in the SBM than til oil cake and MOC. Because, UDP concentration is higher (35\%) in SBM (Preston, 2000) than MOC, which is about $14 \%$ (Negi et al., 1989). Higher amount of CP intake from HP diet in the present study did not improve ( $P>0.05)$ weight gain (2.4 and 2.4 vs. 2.3 and $2.9 \mathrm{~kg})$ and growth rate (42 and 43 vs. 41 and $52 \mathrm{~g} / \mathrm{d}$ ) compared to LP. Sahlu et al., (2004) reported that DM intake, weight gain and feed efficiency were similar between CP levels and sources when 
Bang. J. Anim. Sci. 2009, 38(1\&2)

supplemented from blood meal, corn gluten meal, feather meal, fish meal and soybean meal respectively.

Table 2. Effect of levels and sources of protein supplementation on growth performance of Black Bengal goats

\begin{tabular}{|c|c|c|c|c|c|c|c|c|}
\hline \multirow{2}{*}{ Parameters } & \multicolumn{4}{|c|}{ Dietary treatments $^{\#}$} & \multirow{2}{*}{ SEM } & \multicolumn{3}{|c|}{ Significance of contrast } \\
\hline & $T_{1}$ & $T_{2}$ & $T_{3}$ & $\mathrm{~T}_{4}$ & & $\mathbf{S}$ & $\mathbf{L}$ & $\mathbf{I}$ \\
\hline Initial LW (kg) & 9.20 & 9.15 & 9.12 & 9.18 & 0.31 & NS & NS & NS \\
\hline Final LW (kg) & 11.56 & 11.48 & 11.50 & 12.08 & 0.35 & NS & NS & NS \\
\hline Total LWG (kg) & 2.37 & 2.31 & 2.38 & 2.90 & 0.14 & NS & NS & NS \\
\hline Daily LWG (g) & 42.32 & 41.29 & 42.46 & 51.79 & 2.50 & NS & NS & NS \\
\hline FCE (LWG/DMI) & 0.10 & 0.11 & 0.11 & 0.12 & 0.01 & NS & NS & NS \\
\hline PCE (CPI/LWG) & 1.47 & 1.13 & 1.39 & 0.99 & 0.09 & NS & * & NS \\
\hline Energetic efficiency (MEI/LWG) & 0.11 & 0.09 & 0.11 & 0.09 & 0.01 & NS & NS & NS \\
\hline
\end{tabular}

${ }^{\#} \mathrm{~T}_{1}=$ Mustard oil cake-high protein (22\%), $\mathrm{T}_{2}=$ Mustard oil cake-low protein (16\%), $\mathrm{T}_{3}=$ Soybean meal-high protein (22\%), $\mathrm{T}_{4}=$ Soybean meal-low protein (16\%)

SEM $=$ Standard Error of Mean

NS = Non Significant, $S=$ Main effect of protein sources (MOC vs. SBM), L = Main effect of protein levels (HP vs. $\mathrm{LP}), \mathrm{I}=$ Interaction between protein sources and protein levels

* = Significant $(\mathrm{P}<0.05)$

There was no significant $(P>0.05)$ variation on conversion efficiency of DM both sources and level of protein. The result also showed that conversion efficiency of DM from LP level of SBM and MOC supplemented diet was better than HP. This might be due to the fact that goat consumed higher amount of DM from low protein SBM diet, as a result energy consumption also increased which reflects on improved utilization of energy as well as higher growth performance in goats. Similarly, Bishwas (1997) also showed that high protein diet did not significantly improve conversion efficiency of DM.

The result showed that protein conversion efficiency varied insignificantly between sources but not their levels. Lack of significant variation on growth rate from HP and LP diets may be attributed to the fact that, similar amount of protein available from both protein levels at the small intestine although, there were greater differences in CP intakes between HP and LP level. The major proportion of dietary protein in goats fed HP diets was probably degraded in the rumen with the production of ammonia resulting greater urinary losses of nitrogen. Previous studies with goats given the HP diet $(20.9 \%$ $\mathrm{CP}$ ) indicated that $28 \%$ of the dietary nitrogen was apparently lost across the stomach (Ash and Norton, 1987).

\section{Nutrient intake}

Daily dry matter intake (g/d) from MOC and SBM was 425 and 407 for HP diet but for LP diet it was 389 and 437 respectively (Table 3). Dry matter intake from concentrate mixture were almost similar in all diets but from dal grasses tended to be higher for SBM than MOC supplemented groups. As a result goat consumed higher amount of DM (concentrate plus dal grass) due to supplementation of SBM $(422 \mathrm{~g} / \mathrm{d})$ than MOC 
(407g/d). Thus higher amount of nutrient became available to goats fed SBM diet that may reflect towards higher growth performance.

Table 3. Effect of levels and sources of protein supplementation on nutrient intake of Black Bengal goats

\begin{tabular}{|c|c|c|c|c|c|c|c|c|}
\hline \multirow{2}{*}{ Parameters } & \multicolumn{4}{|c|}{ Dietary treatments } & \multirow{2}{*}{ SEM } & \multicolumn{3}{|c|}{ Significance of contrast } \\
\hline & $\mathrm{T}_{1}$ & $T_{2}$ & $T_{3}$ & $\mathrm{~T}_{4}$ & & $\mathrm{~S}$ & $\mathbf{L}$ & $\mathrm{I}$ \\
\hline \multicolumn{9}{|l|}{ DM intake $(g / d)$} \\
\hline Concentrate & 168.3 & 167.5 & 159.1 & 174.2 & 7.09 & NS & NS & NS \\
\hline Roughage & 256.7 & 221.0 & 248.0 & 262.3 & 10.72 & NS & NS & NS \\
\hline Total & 425.0 & 388.5 & 407.1 & 436.6 & 1.91 & NS & NS & NS \\
\hline DM intake (\% live weight) & 4.15 & 3.76 & 3.95 & 4.11 & 0.10 & NS & NS & NS \\
\hline DM intake $\left(\mathrm{g} / \mathrm{kg}^{0.75} / \mathrm{d}\right)$ & 74.24 & 67.30 & 70.74 & 73.85 & 1.77 & NS & NS & NS \\
\hline Crude protein intake $(\mathrm{g} / \mathrm{d})$ & 58.85 & 45.59 & 56.08 & 50.17 & 2.19 & NS & * & NS \\
\hline CP intake $\left(\mathrm{g} / \mathrm{kg}^{0.75} / \mathrm{d}\right)$ & 10.29 & 7.89 & 9.72 & 8.49 & 0.32 & NS & * & NS \\
\hline ME intake (MJ/d) & 4.59 & 3.73 & 4.61 & 4.46 & 0.17 & NS & * & NS \\
\hline ME intake(MJ/kg $\left.{ }^{0.75} / \mathrm{d}\right)$ & 0.80 & 0.65 & 0.81 & 0.75 & 0.02 & NS & NS & NS \\
\hline CPI: MEI (g/MJ) & 12.96 & 12.46 & 12.19 & 11.39 & 0.48 & NS & NS & NS \\
\hline
\end{tabular}

\# $\mathrm{T}_{1}=$ Mustard oil cake-high protein (22\%), $\mathrm{T}_{2}=$ Mustard oil cake-low protein (16\%), $\mathrm{T}_{3}=$ Soybean meal-high protein (22\%), $\mathrm{T}_{4}=$ Soybean meal-low protein (16\%)

$\mathrm{SEM}=$ Standard Error of Mean

NS = Non Significant, $S=$ Main effect of protein sources (MOC vs. SBM), $L=$ Main effect of protein levels (HP vs. LP), I = Interaction between protein sources and protein levels

* = Significant $(\mathrm{P}<0.05)$

Dry matter intake on the basis of percent live weight was $4.2,3.8,4.0$ and 4.1 percent for the diets $T_{1}, T_{2}, T_{3}$ and $T_{4}$ respectively. There was no variation $(P>0.05)$ on $\mathrm{DMI}$ as percentage of live weight considering both level and sources of protein. Ranjhan (1980) also reported that DMI in goats varied from 1.47 to $3.65 \%$ of live weight. Kabir et al., (2002) also mentioned DMI of Black Bengal goat was $3.46 \%$ of live weight. Daily CP intake $(\mathrm{g} / \mathrm{d})$ from MOC and SBM were 59 and 56 for HP, but 46 and 50 for LP diets respectively. The result showed that $C P$ intake did not differ significantly $(P>0.05)$ in both sources. This result agrees with the result of Rahman (2001) who reported that goat received diets containing different sources of nitrogen did not differ significantly $(P>0.05)$.

\section{Digestibility and nutritive value}

The result showed that there were no significant variation between protein levels (HP and LP) on DM digestibility but in both sources digestibility were higher for HP than LP level (Table 4). Similarly Richardel, (2004) reveled that the DM digestibility of weaned dairy calves was 73 and 75 percent by supplying 16 and 18\% CP from SBM 
Bang. J. Anim. Sci. 2009, 38(1\&2)

supplemented diet respectively. From our result it was also seen that DM digestibility did not differ $(P>0.05)$ between protein levels but numerically higher for high protein level.

Table 4. Effect of levels and sources of protein supplementation on nutrient digestibility of Black Bengal goats

\begin{tabular}{|c|c|c|c|c|c|c|c|c|}
\hline \multirow{2}{*}{ Digestibility (g/100g) } & \multicolumn{4}{|c|}{ Dietary treatments $^{\#}$} & \multirow{2}{*}{ SEM } & \multicolumn{3}{|c|}{ Significance of contrast } \\
\hline & $T_{1}$ & $\mathbf{T}_{2}$ & $\mathbf{T}_{3}$ & $T_{4}$ & & $S$ & $\mathbf{L}$ & 1 \\
\hline DM & 61.47 & 57.79 & 69.18 & 68.26 & 1.69 & * & NS & NS \\
\hline $\mathrm{CP}$ & 61.78 & 59.77 & 69.85 & 68.79 & 1.52 & * & NS & NS \\
\hline CF & 54.67 & 54.46 & 69.29 & 69.77 & 2.28 & * & NS & NS \\
\hline EE & 52.84 & 55.41 & 61.69 & 63.02 & 1.22 & NS & NS & NS \\
\hline NFE & 68.02 & 65.83 & 73.85 & 74.51 & 1.47 & $\star *$ & NS & NS \\
\hline OM & 66.62 & 63.56 & 71.33 & 73.03 & 1.38 & ** & NS & NS \\
\hline
\end{tabular}

${ }^{\#} \mathrm{~T}_{1}=$ Mustard oil cake-high protein (22\%), $\mathrm{T}_{2}=$ Mustard oil cake-low protein (16\%), $\mathrm{T}_{3}=$ Soybean meal-high protein (22\%), $\mathrm{T}_{4}=$ Soybean meal-low protein (16\%)

SEM = Standard Error of Mean

NS = Non Significant, $S=$ Main effect of protein sources (MOC vs. SBM), L = Main effect of protein levels (HP vs.

$\mathrm{LP}), \mathrm{I}=$ Interaction between protein sources and protein levels.

* = Significant $(P<0.05),{ }^{* *}=$ Significant $(P<0.01)$

The result also seen that dry matter digestibility was higher for SBM (69) than MOC (60). Higher digestibility of SBM can be explained by the fact that MOC contain higher amount of glucosinolates. Glucosinolates always accompanied by the enzyme thioglucosidase, which is capable of hydrolyzing glucosinolates to thiocyanates, glucose and acid sulphate and isothiocyanates, as a result, digestibility decrease. Beside these, MOC contain 2.5 to 3.5 percent condensed tannin (Banerjee, 1998) which binds with proteins and thus inhibit the proteolytic enzyme. High tannin also depresses the cellulase activity and affect digestion of $\mathrm{CF}$, thus tannin reduce the digestion of protein and DM.

The result showed that there was a significant variation between MOC and SBM in CP digestibility and higher for SBM than MOC but the values varied $(P>0.05)$ between levels in both sources. Crude protein digestibility of MOC-HP diet was slightly higher than MOC-LP diet. This result conflict with the result of Omar (2002) in which he shown that CP digestibility of $20 \%$ sesame oil cake $(83.0)$ was significantly $(P<0.05)$ higher than $10 \%$ sesame oil cake (79.7). The higher CP digestibility of MOC-HP diet may be due to the fact that the total protein of mustard oil cake contains 14 percent rumen undegraded protein (Negi et al., 1989). Thus, higher amount of UDP available from HP than LP level of mustard oil cake. Crude protein digestibility of SBM supplemented diet was slightly higher for HP level than LP, but the variation was insignificant. Similarly Soto-Navarro et al., (2005) reported insignificant variation in nitrogen digestibility from different level of SBM supplementation.

Organic matter $(\mathrm{OM})$ and nitrogen free extract $(\mathrm{NFE})$ digestibility $(\mathrm{g} / 100 \mathrm{~g})$ were $(P<0.01)$ higher for SBM than MOC but not their levels. Kurar and Mudgal (1980) also reported that energy or protein level had no significant effect on the digestibility of nitrogen free 
extract and energy. EE digestibility from SBM was higher than MOC but between levels slightly higher values were seen for LP than HP in both sources. Sahoo et al., (2008) showed EE digestibility of formaldehyde treated MOC was higher than untreated MOC. Bishwas, (1997) also showed that EE digestibility of LP supplemented diet was higher than HP.

\section{Conclusion}

The result of this experiment shows that performance of goat mostly similar among the treatments. Therefore, it may be concluded that concentrate diet formulated with SBM and/or MOC having $16 \%$ protein could be used for profitable goat rearing.

\section{Literature Cited}

AOAC, 1980. Official methods of analysis (13 ${ }^{\text {th }}$ edition). Association of Official Analytical Chemists. Washington, DC.

Ash, A. J. and Norton, B. W. 1987. Studies with the Australian Cashmere goat. Effects of dietary protein concentration and feeding level on body composition of male and female goats. Australian J. Agric. Res. 38: 971-982.

Banerjee, G. C. 1998. Feeds and Principles of Animal Nutrition. Oxford and IBH publishing Company Private Limited, New Delhi, Calcutta.

BBS, 2008. Bangladesh Bureau of Statistics. Statistical Pocket Book of Bangladesh. Statistics Division, Ministry of Planning, Dhaka Bangladesh.

Bishwas, M. A. A. 1997. Effect of dietary protein concentration and feeding level on growth and carcass characteristics of Black Bengal goats. M.S. Thesis, Department of Animal Nutrition, Bangladesh Agricultural University, Mymensingh-2202.

BLRI, 2002. Goat Production Manual, Published by Bangladesh Livestock Research Institute (BLRI) and Department of Livestock Services (DLS), April, 2002.

Hadjipanayiotou, M., Koumas, A., Hadjigavrie, G., Antoniou, I., Photiou, A. and Theodoridou, M. 1996. Feeding dairy ewes and goats and growing lambs and kids mixture of protein supplements. Small Rumin. Res. 21: 203-211.

Huque, K. S. 2008. A seminar on livestock and poultry production and feed availability in Bangladesh, Bangladesh Livestock Research Institute (BLRI), Saver, Dhaka.

Kabir, F., Sahjalal, M., Chowdhury, S. A., Alam, J., and Islam, M. R. 2002. Effects of protein supplementation to grazing on growth and reproductive performance in female goats and sheep. Pakistan J. Biol. Sci. 5(6): 719-721.

Kochapakdee, S., Pralomkam, S., Saitanoo, A. and Norton, B.W. 1994. Productivity of female goats grazing newly established pasture with varying levels of supplementary feeding. Australasian J. Anim. Sci., 7(2): 289-293.

Kurar, C. K. and Mudgal, V. D. 1980. Effect of plane of nutrition on the utilization of nutrients in dry Beetal goats. Indian J. dairy Sci. 33: 2.

Negi, S. S., Singh, B. and Makkar, H. P. S. 1989. In situ rumen degradation of dry matter and nitrogen in some concentrate feed supplements. Indian J. Anim. Nutr. 6: 1-12.

Omar, J. M. A. 2002. Effect of feeding different levels of sesame oil cake on performance and digestibility of Awassi lambs. Small Rumin. Res. 46: 187-190. 
Bang. J. Anim. Sci. 2009, 38(1\&2)

Preston, R. L. 2000. Typical composition of feeds for cattle and sheep. Beef 36 (10) 10-20. Intertee Publication Company, Overland Park, KS.

Rahman, M. A. 2001. Effect of sources of nitrogen supplementation on growth and reproductive performance of female goats and sheep under grazing condition. M.S. Thesis, Department of Animal Nutrition, Bangladesh Agricultural University, Mymensingh-2202.

Ranjhan, S. K. 1980. Animal Nutrition in the Tropics. Vikas Publishing House Pvt. Ltd. Vikas house, Ghajiabod V.P. (India). pp. 163-167.

Richardel, P. T. 2004. Effect of dietary protein level and fish meal on growth and hormonal status of weaned dairy calves. M.S. Thesis, Louisiana State University and Agricultural and Mechanical College.

Sahlu, T., Goetsch, A. L., Luo, J., Nsahlai, I. V., Moore, J. E., Galyean, M. L., Owens, F. N., Ferrell, C. L. and Johnson, Z. B. 2004. Nutrient requirements of goats: Developed equations, other considerations and future research to improve them. Available on online 10 June 2004.

Sahoo, B. and Walli, T. K. 2008. Effects of formaldehyde treated mustard cake and molasses supplementation on nutrient utilization, microbial protein supply and feed efficiency in growing kids. J. Anim. feed Sci. Technol. Vol. 142 (NO. 3-4).

Shahjalal, M., Galbraith, H., and Topps, J. H. 1992. The effect of changing in dietary protein and energy on growth, body composition, mohair fibre characteristics of British Angora goats. Anim. Prod. 54: 405-412.

Soto-Navarro, S. A., Goetsch, A. L., Sahlu, T., Puchala, R., and Dawson, L. J. 2005. Effect of ruminally degraded nitrogen source and level in a high concentrate diet on site of digestion in Boer- Spanish whether. Institute for Goat Research, Langston University, Langston. 